\title{
A SIMPLE ADULT-MOUSE TEST FOR TISSUE INVASIVENESS IN YERSINIA ENTEROCOLITICA STRAINS OF LOW EXPERIMENTAL VIRULENCE
}

\author{
R. Bakour, G. Balligand, Y. Laroche, G. Cornelis* and G. Wauters \\ Unite de Microbiologie, Université de Louvain, UCL 30.58, B1200 Brussels, Belgium
}

SUMmaRY. The virulence of Yersinia enterocolitica depends on the presence of a 70-kilobase plasmid, called the Vwa plasmid. This situation is particularly favourable for studies of the mechanism of pathogenicity, but these are hindered by the lack of a suitable animal test to monitor the virulence of the human-pathogenic strains isolated outside the USA which belong to serogroups $0: 3,0: 9$ and $0: 5,27$. We observed that, after oral administration to the mouse, the Vwa-positive strains of these serogroups produce a discrete systemic infection while the Vwa-negative strains do not. We present here a simple mouse-virulence test based on this observation.

\section{INTRODUCTION}

Virulent strains of Yersinia enterocolitica harbour a plasmid of about 70 kilobases (kb) (Gemski et al., 1980; Zink et al., 1980) that belongs to the incompatibility group FI (Bakour et al., 1983). The presence of this plasmid, now referred to as the Vwa plasmid, conditions the virulence of $Y$. enterocolitica, as determined for serogroup- 8 strains by invasion of the conjunctival epithelium of guinea-pigs (the Serény test) or by lethality for mice (Gemski et al., 1980).

This $70-\mathrm{kb}$ plasmid encodes calcium dependency at $37^{\circ} \mathrm{C}$ (Higushi and Smith, 1961; Gemski et al., 1980; Portnoy et al., 1984), autoagglutinability at the same temperature (Laird and Cavanaugh, 1980), and resistance to the bactericidal activity of serum (Pai and DeStephano, 1982). The 70-kb plasmid of serogroup- 8 strains also determines the presence in them of the $\mathrm{V}$ and $\mathrm{W}$ antigens of the plague bacillus (Carter et al., 1980; Perry and Brubaker, 1983) and at least four major outer-membrane proteins (Bolin et al., 1982; Portnoy et al., 1984). However, the invasiveness of $Y$. enterocolitica for HeLa cells (Lee et al., 1977; Une, 1977b) is not dependent on this 70-kb plasmid (Schiemann and Devenish, 1982). Similarly, it does not condition invasiveness of $Y$. enterocolitica for human epithelial-tissue cells (HEp-2) but it codes for the detachment of HEp-2 monolayers (Portnoy et al., 1981) and for the adherence of the bacteria to these cells (Vesikari et al., 1981). A second plasmid $(120 \mathrm{~kb})$ is said to be concerned in the

Received 25 Apr. 1984; accepted 20 Jun. 1984.

* Correspondence and reprint requests should be sent to Dr G. Cornelis. 
virulence of strains of serogroups O:8, O:13, 18, O:20 and O:40 (Kay et al., 1982), but will not be considered further in this paper.

A genetic analysis of virulence clearly requires a cheap and easy animal test. Several such tests are available for the aesculin-negative, biotype-1 American strains that belong mainly to serogroup O:8: the Serény test is positive (Feeley et al., 1979; Gemski et al., 1980; Schiemann and Devenish, 1980; Zink et al., 1980) and mice (Carter and Collins, 1974; Quan et al., 1974; Carter, 1975) or gerbils (Wetzler et al., 1968; Quan et al., 1974; Schiemann and Devenish, 1980) die after oral or intraperitoneal inoculation of calcium-dependent cells. However, these tests are inadequate for the human-pathogenic strains isolated outside the USA that belong to serogroups $0: 3,0: 9$ and $0: 5,27$, as well as for members of serogroups $\mathrm{O}: 1$ and $\mathrm{O}: 2$ that are pathogenic for some animals (Wauters, 1970); these strains fail to evoke a keratoconjunctivitis in guinea-pigs (Mollaret and Guillon, 1965; Mors and Pai, 1980; Schiemann et al., 1981; Vesikari et al., 1981) and they do not cause death or clearly identifiable clinical illness in mice (Mollaret and Guillon, 1965; Alonso et al., 1975; Pai and DeStephano, 1982; Aulisio et al., 1983) or gerbils (Schiemann and Devenish, 1980) when given by any route. Nevertheless, in mice, these low-virulence strains are excreted for a long period after oral inoculation (Maruyama et al., 1979; Pearson et al., 1979; Kaneko and Hashimoto, 1983), induce a mild diarrhoea (Laird and Cavanaugh, 1980; Schiemann et al., 1981) and multiply in Peyer's patches (Pai and DeStephano, 1982). The virulence of these strains can be assayed by the intraperitoneal or oral route in nude mice (Alonso et al., 1975), the oral route in axenic mice (Bercovier et al., 1976) or the intraperitoneal route in suckling mice (Aulisio et al., 1983). The addition of iron dextran to an intraperitoneal inoculum leads to some deaths in mice given serogroup-3 or -9 strains, but this is not clearly related to the presence of the $70-\mathrm{kb}$ plasmid (Smith et al., 1981).

We observed that the tissue invasiveness of the "low-virulence" $Y$. enterocolitica strains can be assayed in a simple adult-mouse test: after oral administration to TB (Platteau and Bazin, 1978) or NMRI mice, calcium-dependent strains invade the spleen while calcium-independent isogenic strains do not. This was observed with strains of serogroups $\mathrm{O}: 1, \mathrm{O}: 2, \mathrm{O}: 3, \mathrm{O}: 9$ and $\mathrm{O}: 5,27$.

\section{MATERIALS AND METHODS}

Bacterial strains. Y. enterocolitica strains are listed in table I. All these strains were recloned and tested for calcium dependency, autoagglutinability and presence of the Vwa plasmid. Calcium-independent variants were selected for all the strains that were originally calcium dependent by plating at $37^{\circ} \mathrm{C}$ on magnesium oxalate (MOX) agar (Higushi and Smith, 1961; Schiemann and Devenish, 1980).

Serogrouping. All Y. enterocolitica strains were serotyped by the standard slide-agglutination procedure with type-specific antisera prepared in rabbits (Wauters et al., 1971).

Autoagglutination test. Autoagglutination was detected by comparing overnight cultures grown at $37^{\circ} \mathrm{C}$ and $28^{\circ} \mathrm{C}$ in Tryptic Soy Broth (TSB; Difco).

Calcium dependency. This test was performed by plating at $37^{\circ} \mathrm{C}$, spots of $20 \mu \mathrm{l}$ of a 1 in 100 dilution of an overnight culture grown at $28^{\circ} \mathrm{C}$, on to Tryptic Soy Agar (TSA) (Difco) and MOX agar as described by Schiemann and Devenish (1980).

Vwa-plasmid detection. This was done essentially as described by Kado and Liu (1981). Lysates were incubated for $45 \mathrm{~min}$ at $65^{\circ} \mathrm{C}$. Several strains were also analysed by the method described by Cornelis et al. (1981). Agarose-gel electrophoresis was performed in vertical $0.8 \%$ gels at $30 \mathrm{~V}$ for $20 \mathrm{~h}$. Preparations of the Vwa plasmid of strain 439-80, which was fully 
TABLE I

Strains of Yersinia studied

\begin{tabular}{|c|c|c|c|c|c|}
\hline $\begin{array}{l}\text { Strain } \\
\text { no. }\end{array}$ & $\begin{array}{l}\text { Serogroup } \\
\text { (O antigens) }\end{array}$ & Biogroup & $\begin{array}{l}\text { Calcium dependency, } \\
\text { autoagglutinability, } \\
\text { Vwa plasmid present }\end{array}$ & Origin & Source or reference \\
\hline \multicolumn{6}{|c|}{$Y$. enterocolitica } \\
\hline T1758 & 1 & 3 & + & Beaver & S. Toma: Toronto, Canada \\
\hline IP38 & 2 & 5 & + & Hare & Yersinia Centre, Paris \\
\hline W774 & 3 & 4 & + & Human faeces & This laboratory \\
\hline W783 & 3 & 4 & + & Human faeces & This laboratory \\
\hline W804 & 3 & 4 & + & Human faeces & This laboratory \\
\hline W835 & 3 & 4 & + & Human faeces & This laboratory \\
\hline W845 & 3 & 4 & + & Human faeces & This laboratory \\
\hline L11 & 3 & 4 & + & Pig's tongue & This laboratory \\
\hline $338-80$ & 5 & 1 & - & Human faeces & R. Van Noyen: Belgium \\
\hline 35 & 5 & 1 & - & Pig's tongue & This laboratory \\
\hline $708-82$ & 5,27 & 2 & + & Human faeces & G. Ghysels: Belgium \\
\hline $605-31$ & 5,27 & 2 & + & Human faeces & J. Goudswaard: Netherlands \\
\hline 25 & 6 & 1 & - & Pig's tongue & This laboratory \\
\hline $300-82$ & 6,30 & 1 & - & Human faeces & Coninx: Belgium \\
\hline $\mathrm{Y} 440$ & 7,8 & 1 & - & Human faeces & R. Van Noyen: Belgium \\
\hline $439-80$ & 9 & 2 & + & Human faeces & G. Ghysels: Belgium \\
\hline W22708 & 9 & 2 & + & Human faeces & $\begin{array}{l}\text { G. Cornelis and C. Colson } \\
\text { (1975) }\end{array}$ \\
\hline W818 & 9 & 2 & + & Human faeces & This laboratory \\
\hline W830 & 9 & 2 & + & Human faeces & This laboratory \\
\hline W836 & 9 & 2 & + & Human faeces & This laboratory \\
\hline S6 & 9 & 2 & + & Pig's tongue & This laboratory \\
\hline $301-82$ & 41 & 1 & - & Human faeces & Coninx: Belgium \\
\hline Y. frederikseni & kseni & & - & Human faeces & This laboratory \\
\hline \multirow{2}{*}{\multicolumn{3}{|c|}{$\begin{array}{l}\text { Y. kristenseni } \\
\text { Y438 }\end{array}$}} & & & \\
\hline & 12,25 & & - & Human faeces & R. Van Noyen: Belgium \\
\hline
\end{tabular}

characterised by Laroche et al. (1984), were included in all experiments. Bands corresponding in position with that given by the reference plasmid were taken to indicate the presence of the Vwa plasmid.

Mice. The tests were carried out on adult (2-3-months-old) inbred TB mice (Platteau and Bazin, 1978) and on outbred NMRI mice.

Standard invasiveness test. $Y$. enterocolitica strains were grown at $28^{\circ} \mathrm{C}$ in TSB with shaking at $150 \mathrm{rpm}$ in conical flasks with four baffles. Bacteria were harvested, washed and resuspended in unsterilised drinking water. The $\mathrm{OD}_{660}$ of the suspension was adjusted to $200 \mathrm{~K}$ lett units, which corresponds to $10^{9}$ bacteria $/ \mathrm{ml}$.

Batches of three or four NMRI mice in $15 \mathrm{~cm} \times 21 \mathrm{~cm} \times 13 \mathrm{~cm}$ cages with $75 \mathrm{~g}$ of woodshaving bedding were deprived of water for $24 \mathrm{~h}$ (starting at $6 \mathrm{p} . \mathrm{m}$.), and then each batch was allowed to drink ad libitum for $48 \mathrm{~h}$ from $100 \mathrm{ml}$ of the bacterial suspension. After this, the mice were allowed free access to drinking water for one night. On the next day, the mice were killed with ether and the spleens were removed aseptically. Each spleen was placed in $10 \mathrm{ml}$ of saline and disrupted by a treatment of 15-30 s with an Ultra-turrax TP18 disrupter (instrument also called Takmar in the USA; Janke and Kunkel, W. Germany) equipped with the $18 \mathrm{~K}$ shaft. The bacterial content of the spleen was concentrated by spinning at $1875 \mathrm{~g}$ for $30 \mathrm{~min}$, resuspended in $0.3 \mathrm{ml}$ of saline and plated, eventually after dilution, on MacConkey's agar.

Antibody detection. TB mice were deprived of water for $24 \mathrm{~h}$ and then allowed to drink a suspension of $10^{9}$ Y. enterocolitica $/ \mathrm{ml}$ for $24 \mathrm{~h}$. They were then placed in a cold room $\left(4^{\circ} \mathrm{C}\right)$ for 6 days and killed on the 7 th day after inoculation. The mice were bled from the heart under ether anaesthesia. After coagulation, the serum was used in slide- and tube-agglutination tests. For the latter test, the bacterial suspension was treated with merthiolate $(0 \cdot 2 \%$ final concentration $)$ and adjusted to a density of MacFarland No. 2 standard. 


\section{RESULTS}

\section{Recovery of Vwa-positive strains from the spleen}

Preliminary observations (data not shown) revealed that Vwa-positive $\left(\mathrm{Vwa}^{+}\right)$ strain 439-80 did not cause death or illness in TB mice after oral inoculation but invaded deep organs such as the spleen and the liver. Further experiments were performed with this strain to define the optimal conditions for detection of bacteria in the spleen. Some batches of TB mice were placed at $4^{\circ} \mathrm{C}$ to assess the effect of slight stress on the recovery of $Y$. enterocolitica from the spleen. Mice, 3-4 per cage (as described in Materials and methods) were placed for 6 days, without previous acclimatization, at $4^{\circ} \mathrm{C}$ in a large lit cold-room, after they had drunk (at room temperature) the bacterial suspension for $24 \mathrm{~h}$. The stay at $4^{\circ} \mathrm{C}$ seemed to increase the number of bacteria recovered from the spleen, and day 7 appeared to be the most appropriate one to kill the mice. Under these conditions, the Vwa ${ }^{+}$strain 439-80 was always recovered from the spleen while the Vwa-negative $\left(\mathrm{Vwa}^{-}\right)$variant of the same strain was detected in only two of 17 mice and in much lower number (table II). Under the same conditions, the test was then applied to the 16 strains of $Y$. enterocolitica from serogroups $\mathrm{O}: 1, \mathrm{O}: 2, \mathrm{O}: 3, \mathrm{O}: 5,27$ and $\mathrm{O}: 9$. All these strains and their calcium-independent variants were also checked for the presence of the Vwa plasmid by agar-gel electrophoresis. Calcium dependency was in each case associated with the presence of a plasmid of about $70 \mathrm{~kb}$. In addition, strain IP38 (O:2) was found to contain a second plasmid of higher mol. wt. As shown in table II, all the $\mathrm{Vwa}^{+}$strains invaded the spleen ( 60 out of 62 mice). Counts were generally in the range of 1000 bacteria per spleen but with great variations between individual mice of the same batch. On the contrary, the $\mathrm{Vwa}^{-}$strains could only be recovered from the spleens of 3 out of 61 mice and the counts were extremely low in these exceptional cases ( $<10$ bacteria per spleen).

Besides these strains of low experimental virulence, six aesculin-positive $Y$. enterocolitica strains from biogroup 1 and two strains recently classified as $Y$. frederikseni and Y. kristenseni (Bercovier et al., 1980) were also tested. Such strains have never been found, up to now, to be calcium dependent. None of them harboured a $70-\mathrm{kb}$ plasmid. However, strain 301-82 (O:41) has a plasmid clearly smaller than $70 \mathrm{~kb}$ and the $Y$. frederikseni strain $\mathrm{S} 42$ has also a plasmid, larger than $70 \mathrm{~kb}$ (data not shown). None of these strains was found to invade the spleen of the mice: only one colony was recovered from the spleen of 32 mice (table II).

To determine whether this observation requires the particular TB mouse strain, we repeated the experiment with outbred NMRI mice. The animals were allowed to swallow the bacterial suspension for $48 \mathrm{~h}$ and then placed at $4^{\circ} \mathrm{C}$ for the duration of the experiment. The animals were killed on day 3, 5 or 7 after they started drinking the bacterial suspension. As shown in table III, the invasion of the spleen by $\mathrm{Vwa}^{+}$strains was clearly demonstrated.

For ethical reasons, the need for keeping the animals at $4{ }^{\circ} \mathrm{C}$ was re-evaluated. Comparative experiments were performed with NMRI mice. After drinking the bacterial suspension for $48 \mathrm{~h}$, some batches of mice were placed in the cold room and some batches were kept at room temperature as described in the standard procedure. The comparative experiment was done with six different strains of $Y$. enterocolitica from four different serogroups (table IV). The test gave satisfactory results when the 
TABLE II

Invasion of the spleen by strains of Yersinia bearing the $V w a$ plasmid $\left(\mathrm{Vwa}^{+}\right)$, and by $V$ wa-negative variants or strains $\left(V_{w a}^{-}\right)$, in TB mice kept at $4^{\circ} \mathrm{C}$

\begin{tabular}{|c|c|c|c|c|c|c|c|c|c|}
\hline \multirow{2}{*}{$\begin{array}{l}\text { Strain } \\
\text { no. }\end{array}$} & \multirow[b]{2}{*}{ Serogroup } & \multicolumn{4}{|c|}{$\begin{array}{l}\mathrm{Vwa}^{+} \text {form } \\
\text { Number of bacteria/spleen } \\
\text { of mouse no. }\end{array}$} & \multicolumn{4}{|c|}{$\begin{array}{l}\mathrm{Vwa}^{-} \text {form } \\
\text { Number of bacteria/spleen } \\
\text { of mouse no. }\end{array}$} \\
\hline & & 1 & 2 & 3 & 4 & 1 & 2 & 3 & 4 \\
\hline \multirow{6}{*}{\multicolumn{2}{|c|}{$\begin{array}{l}\text { Y. enterocolitica } \\
439-80\end{array}$}} & & & & & & & & \\
\hline & & $3 \times 10^{4}$ & $5 \times 10^{4}$ & $1 \times 10^{5}$ & & 0 & 0 & 0 & \\
\hline & & $1 \times 10^{5}$ & $5 \times 10^{4}$ & $2 \times 10^{6}$ & $3 \times 10^{5}$ & 0 & 0 & 0 & 0 \\
\hline & & $1 \times 10^{4}$ & $1 \times 10^{3}$ & $2 \times 10^{4}$ & & 0 & 0 & 0 & \\
\hline & & $8 \times 10^{3}$ & $8 \times 10^{3}$ & $4 \times 10^{3}$ & $2 \times 10^{5}$ & 0 & 0 & 0 & 7 \\
\hline & & $7 \times 10^{1}$ & $6 \times 10^{1}$ & $2 \times 10^{2}$ & & 0 & 0 & 1 & $\ldots$ \\
\hline W22708 & 9 & $3 \times 10^{1}$ & $2 \times 10^{3}$ & $5 \times 10^{3}$ & $\ldots$ & 0 & 0 & 0 & $\ldots$ \\
\hline W818 & 9 & $3 \times 10^{2}$ & $3 \times 10^{2}$ & $1 \times 10^{3}$ & $\ldots$ & 0 & 0 & 0 & $\ldots$ \\
\hline W830 & 9 & $1 \times 10^{4}$ & $2 \times 10^{4}$ & $1 \times 10^{3}$ & $\ldots$ & 0 & 0 & 0 & $\ldots$ \\
\hline W836 & 9 & $1 \times 10^{5}$ & $1 \times 10^{3}$ & $1 \times 10^{5}$ & $\ldots$ & 0 & 0 & 0 & $\ldots$ \\
\hline S6 & 9 & $1 \times 10^{4}$ & $1 \times 10^{4}$ & $1 \times 10^{3}$ & $\ldots$ & 0 & 0 & 0 & $\ldots$ \\
\hline W774 & 3 & $1 \times 10^{5}$ & $6 \times 10^{5}$ & $3 \times 10^{5}$ & $\ldots$ & 0 & 0 & $\mathrm{x}$ & $\ldots$ \\
\hline W783 & 3 & 8 & $2 \times 10^{3}$ & $2 \times 10^{2}$ & $\ldots$ & 0 & 0 & 0 & $\ldots$ \\
\hline W804 & 3 & $5 \times 10^{5}$ & $6 \times 10^{3}$ & $5 \times 10^{2}$ & $\ldots$ & 0 & 0 & 0 & $\ldots$ \\
\hline W835 & 3 & 6 & 6 & $1 \times 10^{3}$ & $\ldots$ & 0 & 0 & 0 & $\ldots$ \\
\hline W845 & 3 & $1 \times 10^{3}$ & $1 \times 10^{6}$ & $7 \times 10^{2}$ & $\ldots$ & 0 & 0 & 8 & $\ldots$ \\
\hline L11 & 3 & $1 \times 10^{2}$ & $1 \times 10^{2}$ & $1 \times 10^{3}$ & $\ldots$ & 0 & 0 & 0 & $\ldots$ \\
\hline T1758 & 1 & $4 \times 10^{2}$ & $5 \times 10^{2}$ & $6 \times 10^{3}$ & $\ldots$ & 0 & 0 & 0 & $\ldots$ \\
\hline IP38 & 2 & 0 & $5 \times 10^{2}$ & $2 \times 10^{1}$ & $\ldots$ & 0 & 0 & 0 & $\ldots$ \\
\hline $708-82$ & 5,27 & 0 & $5 \times 10^{1}$ & $5 \times 10^{2}$ & $\ldots$ & 0 & 0 & 0 & $\ldots$ \\
\hline 605-31 & 5,27 & $7 \times 10^{2}$ & $9 \times 10^{1}$ & $3 \times 10^{2}$ & $\ldots$ & 0 & 0 & 0 & $\ldots$ \\
\hline $338-80$ & 5 & $\ldots$ & $\ldots$ & $\ldots$ & $\ldots$ & 0 & 0 & 0 & 0 \\
\hline & 5 & $\ldots$ & $\ldots$ & $\ldots$ & $\ldots$ & 0 & 0 & 0 & 0 \\
\hline 25 & 6 & $\ldots$ & $\ldots$ & $\ldots$ & $\ldots$ & 0 & 0 & 0 & 0 \\
\hline $300-82$ & 6,39 & $\ldots$ & $\ldots$ & $\ldots$ & $\ldots$ & 0 & 0 & 0 & 0 \\
\hline Y440 & 7,8 & $\ldots$ & $\ldots$ & $\ldots$ & $\ldots$ & 0 & 0 & 0 & 1 \\
\hline $301-82$ & 41 & $\ldots$ & $\ldots$ & $\ldots$ & $\ldots$ & 0 & 0 & 0 & 0 \\
\hline \multicolumn{2}{|c|}{$Y$. frederikseni } & & & & & & & & \\
\hline $\mathrm{S} 42$ & 3 & $\ldots$ & $\ldots$ & $\ldots$ & $\ldots$ & 0 & 0 & 0 & 0 \\
\hline \multicolumn{2}{|c|}{ Y. kristenseni } & $\ldots$ & $\ldots$ & $\ldots$ & $\ldots$ & 0 & 0 & 0 & 0 \\
\hline
\end{tabular}

$\mathrm{x}=$ Mouse died before day 7 .

TABLE III

Invasion of the spleen by $\mathrm{Wwa}^{+}$and $V w a^{-}$forms of two strains of Y. enterocolitica in NMRI mice kept at $4^{\circ} \mathrm{C}$ and killed 3,5 or 7 days after infection

\begin{tabular}{|c|c|c|c|c|c|c|c|c|c|c|}
\hline \multirow{2}{*}{$\begin{array}{l}\text { Strain } \\
\text { no. }\end{array}$} & \multirow[b]{2}{*}{ Serogroup } & \multirow{2}{*}{$\begin{array}{c}\text { Killed } \\
\text { on } \\
\text { day }\end{array}$} & \multicolumn{4}{|c|}{$\begin{array}{l}\mathrm{Vwa}^{+} \text {form } \\
\text { Number of bacteria/spleen } \\
\text { in mouse no. }\end{array}$} & \multicolumn{4}{|c|}{$\begin{array}{l}\mathrm{Vwa}^{-} \text {form } \\
\text { Number of bacteria/spleen } \\
\text { in mouse no. }\end{array}$} \\
\hline & & & 1 & 2 & 3 & 4 & 1 & 2 & 3 & 4 \\
\hline $439-80$ & 9 & $\begin{array}{l}3 \\
5 \\
7\end{array}$ & $\begin{array}{l}2 \times 10^{4} \\
7 \times 10^{3} \\
1 \times 10^{3}\end{array}$ & $\begin{array}{l}1 \times 10^{4} \\
1 \times 10^{2} \\
5 \times 10^{2}\end{array}$ & $\begin{array}{l}3 \times 10^{2} \\
5 \times 10^{2} \\
3 \times 10^{2}\end{array}$ & $\begin{array}{c}0 \\
8 \times 10^{2} \\
5 \times 10^{2}\end{array}$ & $\begin{array}{l}0 \\
0 \\
0\end{array}$ & $\begin{array}{l}0 \\
0 \\
0\end{array}$ & $\begin{array}{l}0 \\
0 \\
0\end{array}$ & $\begin{array}{l}0 \\
0 \\
6\end{array}$ \\
\hline W774 & 3 & $\begin{array}{l}3 \\
5 \\
7\end{array}$ & $\begin{array}{l}6 \times 10^{3} \\
3 \times 10^{3} \\
1 \times 10^{3}\end{array}$ & $\begin{array}{l}9 \times 10^{2} \\
3 \times 10^{3} \\
1 \times 10^{3}\end{array}$ & $\begin{array}{l}2 \times 10^{2} \\
2 \times 10^{4} \\
1 \times 10^{3}\end{array}$ & $\begin{array}{l}3 \times 10^{2} \\
3 \times 10^{3} \\
1 \times 10^{3}\end{array}$ & $\begin{array}{l}0 \\
0 \\
0\end{array}$ & $\begin{array}{l}0 \\
0 \\
0\end{array}$ & $\begin{array}{l}0 \\
0 \\
0\end{array}$ & $\begin{array}{l}0 \\
0 \\
0\end{array}$ \\
\hline
\end{tabular}




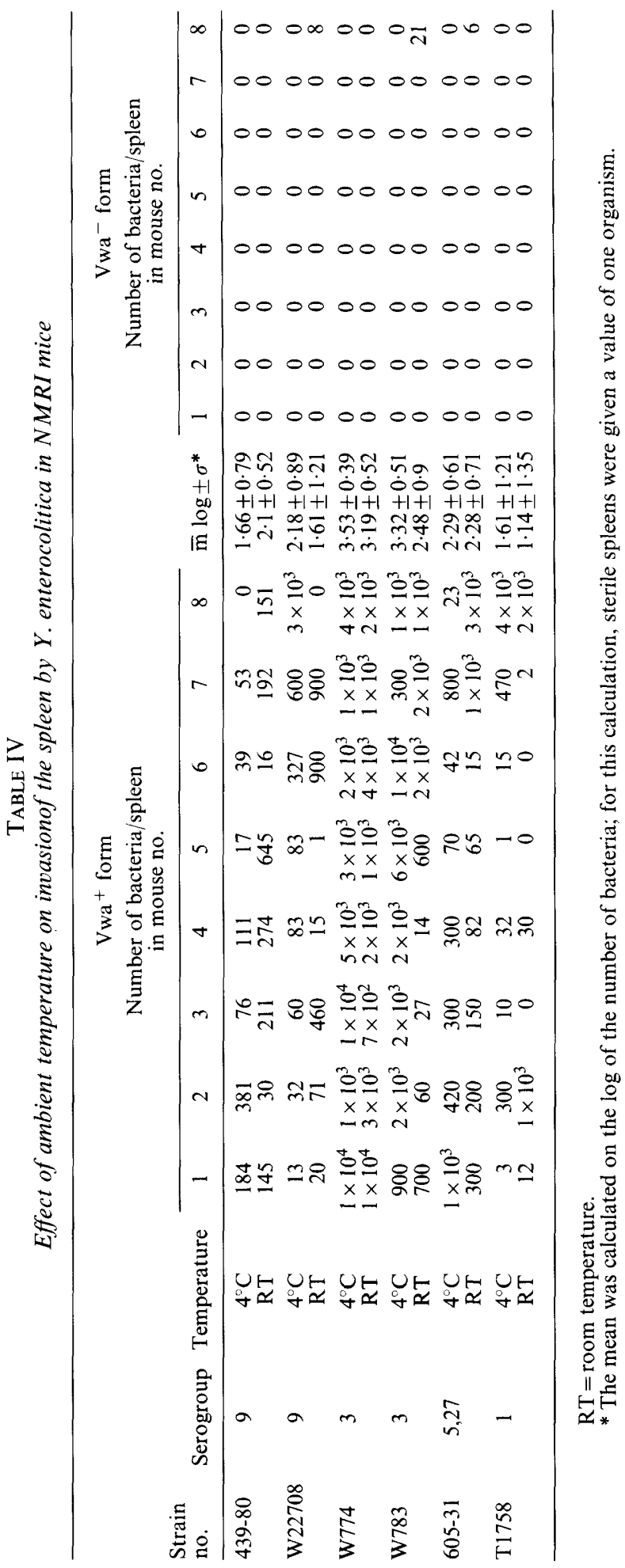


animals were kept at room temperature. In this experiment strain T1758 (serogroup 1) gave somewhat lower mean counts than those shown in table I, irrespective of the temperature conditions. This difference may perhaps be attributed to the different mouse strains used.

\section{Pathological examination}

The invasion of the spleen was confirmed by histological examination. Three positive spleens of NMRI mice that yielded c. $10000 \mathrm{Y}$. enterocolitica of strain 439-80 per spleen showed focal accumulation of clusters of histiocytic cells in the red pulp, without necrosis (data not shown).

\section{Antibody production}

The serum of TB mice infected with $\mathrm{Vwa}^{+}$and $\mathrm{Vwa}^{-}$cultures of $Y$. enterocolitica strain 439-80, kept at $4^{\circ} \mathrm{C}$, and killed on day 7 , agglutinated the homologous strain. Titres were in the range of 100 , and there was no significant difference between mice infected with the $\mathrm{Vwa}^{+}$or $\mathrm{Vwa}^{-}$cultures.

\section{Recovery of $Y$. enterocolitica from the mesenteric lymph nodes}

The detection of anti- $Y$. enterocolitica antibodies in the sera of TB mice infected with the $\mathrm{Vwa}^{-}$strain 439-80 prompted us to look for yersiniae in the mesenteric lymph nodes. In 11 experiments with serogroup $0: 3$ and $O: 9$ strains, mesenteric lymph nodes were collected, ground and inoculated on to plates of MacConkey's agar. Bacteria were recovered from 27 out of 35 lymph nodes from mice infected with $\mathrm{Vwa}^{+}$strains and from 19 of 34 lymph nodes of mice infected with the $\mathrm{Vwa}^{-}$strains.

\section{Discussion}

In the conditions described, $Y$. enterocolitica strains of "low experimental virulence" cross the intestinal barrier of the mouse, reach the mesenteric lymph nodes and elicit a weak humoral immune response, independently of the presence of the Vwa plasmid. $\mathrm{Vwa}^{+}$strains in addition produce an asymptomatic systemic infection and can be detected, between days 3 and 7 after inoculation, in the spleen. The histological examination of the spleen revealed focal accumulation of histiocytic cells but no clear abcesses.

To our knowledge, and quite surprisingly, this has not been described before. Mollaret and Guillon (1965) and, later, Alonso et al. (1975) examined the spleens of mice infected orally with $Y$. enterocolitica of serotypes $0: 3$ and $0: 9$. These authors observed no morbidity and, unlike us, found that the spleens were sterile; however, their examinations were made at days 30 or 90 instead of days 3-7. Moreover, these studies were conducted before the Vwa plasmid had been described and it is not known whether or not the strains used had the Vwa plasmid. Since the description of this plasmid (Gemski et al., 1980; Zink et al., 1980), a few authors have studied again the experimental pathogenicity of the $Y$. enterocolitica strains of "low experimental virulence" in the adult mouse (Schiemann et al., 1981; Smith et al., 1981; DeStephano, 
1982; Schiemann and Devenish, 1982; Aulisio et al., 1983) but they focused on diarrhoea, long-term excretion or lethality.

The present observation thus shows that $\mathrm{Vwa}^{+}$strains of "low experimental virulence", given orally, produce a discrete systemic infection in the mouse. This is in agreement with the observation of Une (1977a) that O:3 and 0:9 strains, given intragastrally to the rabbit produced granulomas in the spleen, accompanied by bacterial localisation in this organ.

It is worth noting that the aesculin-positive strains from biogroup 1, and the $Y$. frederikseni and Y. kristenseni strains, behaved like the $\mathrm{Vwa}^{-}$variants of the strains of low experimental virulence. This is not unexpected, because these strains are $\mathrm{Vwa}^{-}$and were found to be avirulent in all the previous experimental studies (Une, 1977a, Schiemann et al., 1981). Moreover, prevalence studies in healthy persons and in patients suffering from diarrhoea suggest that these strains are not pathogenic for man (Van Noyen et al., 1981).

Our main purpose in studying experimental infection in the mouse was not the description of the physiopathology of the infected mouse but rather the establishment of an easy test to monitor invasiveness for use in molecular-biology studies of the pathogenicity of $Y$. enterocolitica $\mathrm{O}: 3, \mathrm{O}: 9$ and $\mathrm{O}: 5,27$. In particular, we are at present using this test to localise virulence genes on the Vwa plasmids of these strains. In some of the experiments reported in this paper the mice were kept at $4^{\circ} \mathrm{C}$. It became clear from our later work that this is not necessary for the detection of invasiveness. We thus strongly recommend performing the test at room temperature as we have described. This test is thus comparable with other mouse tests, such as mouse-diarrhoea (MD) (Laird and Cavanaugh, 1980; Schiemann et al., 1981), the measure of faecal excretion or intestinal colonization (Schiemann et al., 1981; Pai and DeStephano, 1982), the observation of bacterial multiplication in the Peyer's patches (Pai and DeStephano, 1982) and lethality in 1-3-day-old mice (Aulisio et al., 1983). In this respect, the spleen test appears to be particularly easy to perform and to interpret in comparism with some of the other tests. Although the MD test is probably simpler than the spleen test, some authors have found diarrhoea in mice difficult to define (Pai and DeStephano, 1982; Aulisio et al., 1983). The molecular biologist would probably find the spleen easier to excise than the Peyer's patches. Maintaining a regular supply of suckling mice may well complicate the laboratory's mouse-breeding programme. The spleen test should perhaps be coupled with the measure of the ability to colonize the intestine (Ricciardi et al., 1978; Pai and DeStephano, 1982) because these two tests reveal different aspects of the pathogenicity of $Y$. enterocolitica that might depend on different plasmid genes.

We are indebted to H. Bazin and B. Platteau for the TB mice and to $H$. Noël for the histological examination. We also thank M. Van Bouchaute for her help in the preparation of the manuscript. This work was supported by grant no. 3.4514 .83 from the Belgian FRSM (Fonds de la Recherche Scientifique Medicale).

\section{REFERENCES}

Alonso J M, Bercovier H, Destombes $\mathrm{P}$, Mollaret H H 1975 Pouvoir pathogène expérimental de Yersinia enterocolitica chez la souris athymique (nude). Annales de Microbiologie (Institut Pasteur) 126 B:187-199.

Aulisio C C G, Hill W E, Stanfield J T, Sellers R L 1983 Evaluation of virulence factor testing 
and characteristics of pathogenicity in Yersinia enterocolitica. Infection and Immunity 40:330-335.

Bakour R, Laroche Y, Cornelis G 1983 Study of the incompatibility and replication of the $70-\mathrm{kb}$ virulence plasmid of Yersinia. Plasmid 10:279-289.

Bercovier H, Alonso J M, Destombes P, Mollaret H H 1976 Infection expérimentale de souris axéniques par Yersinia enterocolitica. Annales de Microbiologie (Institut Pasteur) 127 A:493-501.

Bercovier H, Brenner D J, Ursing J, Steigerwalt A G, Fanning G R, Alonso J M, Carter G P, Mollaret H H 1980 Characterization of Yersinia enterocolitica sensu stricto. Current Microbiology 4:201-206.

Bolin I, Norlander L, Wolf-Watz H 1982 Temperature-inducible outer membrane protein of Yersinia pseudotuberculosis and Yersinia enterocolitica is associated with the virulence plasmid. Infection and Immunity 37:506-512.

Carter P B 1975 Pathogenicity of Yersinia enterocolitica for mice. Infection and Immunity 11:164-170.

Carter P B, Collins F M 1974 Experimental Yersinia enterocolitica infection in mice: Kinetics of growth. Infection and Immunity 9:851-857.

Carter P B, Zahorchak R J, Brubaker R R 1980 Plague virulence antigens from Yersinia enterocolitica. Infection and Immunity 28:638-640.

Cornelis G, Colson C 1975 Restriction of DNA in Yersinia enterocolitica detected by recipient ability for a derepressed R factor from Escherichia coli. Journal of General Microbiology 87:285-291.

Cornelis G., Van Bouchaute M, Wauters G 1981 Plasmid-encoded lysine decarboxylation in Proteus morganii. Journal of Clinical Microbiology 14:365-369.

Feeley J C, Wells J G, Tsai T F, Puhr N D 1979 Detection of enterotoxigenic and invasive strains of Yersinia enterocolitica. Contributions to Microbiology and Immunology 5:329-334.

Gemski P, Lazere J R, Casey T 1980 Plasmid associated with pathogenicity and calcium dependency of Yersinia enterocolitica. Infection and Immunity 27:682-685.

Higuchi K, Smith J L 1961 Studies on the nutrition and physiology of Pasteurella pestis. VI. A differential plating medium for the estimation of the mutation rate to avirulence. Journal of Bacteriology 81:605-608.

Kado C I, Liu S-T 1981 Rapid procedure for detection and isolation of large and small plasmids. Journal of Bacteriology 145:1365-1373.

Kaneko K, Hashimoto N 1983 Fecal excretion associated with $\mathrm{Ca}^{2+}$ dependency of Yersinia enterocolitica $\mathrm{O} 3$ and $\mathrm{O} 9$ and Yersinia pseudotuberculosis in mice. Microbiology and Immunology 27:199-202.

Kay B A, Wachsmuth K, Gemski P 1982 New virulence-associated plasmid in Yersinia enterocolitica. Journal of Clinical Microbiology 15:1161-1163.

Laird W J, Cavanaugh D C 1980 Correlation of autoagglutination and virulence of Yersiniae. Journal of Clinical Microbiology 11:430-432.

Laroche Y, Van Bouchaute M, Cornelis G 1984 A restriction map of virulence plasmid pVYE439-80 from a serogroup 9 Yersinia enterocolitica strain. Plasmid 12:67-70.

Lee W H, McGrath P P, Carter P H, Eide E L 1977 The ability of some Yersinia enterocolitica strains to invade HeLa cells. Canadian Journal of Microbiology 23:1714-1722.

Maruyama T, Une T, Zen-Yoji H 1979 Observations on the correlation between pathogenicity and serovars of Yersinia enterocolitica by the assay applying cell culture system and experimental mouse infection. Contributions to Microbiology and Immunology 5:317-323.

Mollaret H H, Guillon J C 1965 Contribution à l'étude d'un nouveau groupe de germes (Yersinia enterocolitica) proches du bacille de Malassez et Vignal. II. Pouvoir pathogène expérimental. Annales de l'Institut Pasteur 109:608-613.

Mors V, Pai C H 1980 Pathogenic properties of Yersinia enterocolitica. Infection and Immunity 28: 292-294.

Pai C H, DeStephano L 1982 Serum resistance associated with virulence in Yersinia enterocolitica. Infection and Immunity 35:605-611.

Pearson A D, Ricciardi I D, Wright D H, Suckling W G 1979 An experimental study of the pathology and ecology of Yersinia enterocolitica infection in mice. Contributions to Microbiology and Immunity 5:335-345. 
Perry R D, Brubaker R R $1983 \mathrm{Vwa}^{+}$phenotype of Yersinia enterocolitica. Infection and Immunity 40:166-171.

Platteau B, Bazin H 1978 TB mice. A model of high and long lasting reaginic responders. Journal of Immunological Methods 20:53-59.

Portnoy D A, Moseley S L, Falkow S 1981 Characterization of plasmids and plasmid-associated determinants of Yersinia enterocolitica pathogenesis. Infection and Immunity 31:775-782.

Portnoy D A, Wolf-Watz H, Bolin I, Beeder A B, Falkow S 1984 Characterization of common virulence plasmids in Yersinia species and their role in the expression of outer membrane proteins. Infection and Immunity 43:108-114.

Quan T J, Meek J L, Tsuchiya K R, Hudson B W, Barnes A M 1974 Experimental pathogenicity of recent north american isolates of Yersinia enterocolitica. Journal of Infectious Diseases 129:341-344.

Ricciardi I D, Pearson A D, Suckling W G, Klein C 1978 Long-term fecal excretion and resistance induced in mice infected with Yersinia enterocolitica. Infection and Immunity 21:342-344.

Schiemann D A, Devenish J A 1980 Virulence of Yersinia enterocolitica determined by lethality in mongolian gerbils and by the Serény test. Infection and Immunity 29:500-506.

Schiemann D A, Devenish J A 1982 Relationship of HeLa cell infectivity to biochemical, serological, and virulence characteristics of Yersinia enterocolitica. Infection and Immunity 35, 497-506.

Schiemann D A, Devenish J A, Toma S 1981 Characteristics of virulence in human isolates of Yersinia enterocolitica. Infection and Immunity 32:400-403.

Smith R E, Carey A M, Damare J M, Hetrick F M, Johnston R W, Lee W H 1981 Evaluation of iron dextran and mucin for enhancement of the virulence of Yersinia enterocolitica serotype $\mathrm{O}: 3$ in mice. Infection and Immunity 34:550-560.

Une T 1977a Studies on the pathogenicity of Yersinia enterocolitica. I. Experimental infection in rabbits. Microbiology and Immunology 21:341-363.

Une T $1977 b$ Studies on the pathogenicity of Yersinia enterocolitica. II. Interaction with cultured cells in vitro. Microbiology and Immunology 21:365-377.

Van Noyen R, Vandepitte J, Wauters G, Selderslaghs R 1981 Yersinia enterocolitica: its isolation by cold enrichment from patients and healthy subjects. Journal of Clinical Pathology 34:1052-1056.

Vesikari T, Nurmi T, Maki M, Skurnik M, Sundqvist C, Granfors K, Gronroos P 1981 Plasmids in Yersinia enterocolitica serotypes O:3 and O:9: correlation with epithelial cell adherence in vitro. Infection and Immunity 33:870-876.

Wauters G 1970 Contribution à l'étude de Yersinia enterocolitica. Vander, Louvain, Belgium.

Wauters G, Le Minor L, Chalon A M 1971 Antigènes somatiques et flagellaires des Yersinia enterocolitica. Annales de l'Institut Pasteur 120:631-642.

Wetzler T F, French M L, Tomas J A 1968 Experimental pathogenesis by Yersinia enterocolitica. Bacteriological Proceedings Abstr.M46, p73.

Zink D L, Feeley J C, Wells J G, Vanderzant C, Vickery J C, Roof W D, O'Donovan G A 1980 Plasmid-mediated tissue invasiveness in Yersinia enterocolitica. Nature 283:224-226. 